\title{
Endothelial keratoplasty: evolution and horizons
}

\section{Transplante endotelial de córnea: evolução e horizontes}

\author{
Gustavo Teixeira Grottone ${ }^{1}$, Nicolas Cesário Pereira ${ }^{1}$, José Álvaro Pereira Gomes ${ }^{1}$
}

\begin{abstract}
Endothelial keratoplasty has been adopted by corneal surgeons worldwide as an alternative to penetrating keratoplasty (PK) in the treatment of corneal endothelia disorders. Since the first surgeries in 1998, different surgical techniques have been used to replace the diseased endothelium. Compared with penetrating keratoplasty, all these techniques may provide faster and better visual rehabilitation with minimal change in refractive power of the transplanted cornea, minimal in duced astigmatism, elimination of suture-induced complications and late wound dehiscence, and a reduced demand for postoperative care. Translational research involving cell-based therapy is the next step in work on endothelial keratoplasty. The present review updates information on comparisons among different techniques and predicts the direction of future treatment.
\end{abstract}

Keywords: Endothelium, corneal/pathology; Corneal transplantation; Descemet stripping endothelial keratoplasty/methods; Keratoplasty, penetrating/methods; Translational medical research; Cell transplantation

\section{RESUMO}

O transplante endotelial tem sido utilizado por cirurgiões de córnea em to do o mundo como uma alternativa ao transplante penetrante no tratamento das desordens do endotélio corneano. Desde as primeiras cirurgias em 1998, diferentes técnicas cirúrgicas tem sido utilizadas para substituir o endotélio doente. Comparadas ao transplante penetrante, estas técnicas oferecem uma reabilitação visual melhor e mais rápida com mínima alteração do poder refrativo da córnea transplantada, mínimo astigmatismo induzido, eliminação das complicações induzidas pela sutura e deiscência tardia da incisão, além de menor necessidade de cuidados pós-operatórios. Pesquisas translacionais envolvendo terapias celulares são o próximo passo em transplantes endoteliais. Este artigo contém uma fonte de dados atualizada comparando diferentes técnicas e futuros tratamentos.

Descritores: Epitélio posterior/patologia; Transplante de córnea; Ceratoplastia endotelial com remoção da membrana de Descemet/métodos; Ceratoplastia penetranting/métodos; Pesquisa médica translacional; Transplante de células

\section{INTRODUCTION}

Corneal transplantation is a major concern of public healthcare management. In the year 2000, a total of 46,949 corneas were available for transplantation from USA eye banks. Although diagnostic data differ, 22.3\% of corneal transplant patients required corneal grafts in 2000 to treat bullous keratopathy ${ }^{(1)}$. During the past 10 years, diagnoses requiring transplantation have changed because of advances in cataract surgery and new indications for lamellar keratoplasty ${ }^{(2)}$. In 2010, the major diagnosed cause for corneal endothelial transplantation in the USA was Fuchs dystrophy, which was responsible for more than $51 \%$ of endothelial keratoplasties. And following the same trend in 2011, 48\% of endothelial keratoplasties were indicated because of Fuchs dystrophy ${ }^{(3)}$. As Li and Mannis has indicated ${ }^{(4)}$, contemporary corneal surgery made a major change in eye banking with the introduction of endothelial keratoplasty (EK). In 2005, only 1,429 EK procedures were performed in the USA; this increased exponentially to 18,221 in 2009 , representing $30.5 \%$ of all corneal grafts in the USA. A trend toward decreased use of penetrating keratoplasty (PK) is also discernible. In 2005, 45,821 corneal grafts were placed; this decreased to 23,269 in $2009^{(5)}$. The trends on EK increasing ratios are still present. From 2009 to 2011, EBAA report showed a consolidated number of $17.6 \%$ more EK procedures. Also a decline of almost 34\% on PK procedures was reported from 2008 to $2011^{(3)}$. This represents the increasing adoption of EK by corneal surgeons to treat endothelial diseases.
The present review analyzes the main outcomes of EK using different surgical techniques, and discusses trends that point toward EK developments in the near future.

\section{The PAST: PENETRATING DEEPLY INTO THE CORNEA}

Penetrating keratoplasty (PK) was the mainstay treatment of the $20^{\text {th }}$ century for corneal endothelial disease. It involves the replacement of full-thickness corneal host tissue by a full-thickness donor, sutured to the host rim. The surgical technique is relatively simple compared to posterior lamellar procedures (Figures 1 and 2). However, good visual outcomes are often limited by high or irregular astigmatism that may require rigid contact lenses or other surgical procedures such as corneal rings, astigmatic keratotomy and excimer laser ablation to achieve good visual results. Corneal curvature and induced astigmatism are suture-dependent, so many months are required to achieve visual stability. PK can be associated with ocular surface and suture-related complications. In addition, globe instability can lead to devastating expulsive hemorrhage intraoperatively or postoperatively after ocular trauma and wound dehiscence. In the 1960s, Dr. Jose Barraquer described a method to selectively replace the diseased endothelium. An anterior approach via a corneal flap could be used to trephine posterior stroma, with Descemet's membrane and endothelium, and replace it with a donor graft sutured in place $^{(6)}$. Vascular ingrowth at the host-donor interface and technique-
Funding: No specific financial support was available for this study.

Disclosure of potential conflicts of interest: G.T.Grottone, None; N.C.Pereira, None; J.A.P.Gomes, None.

Corresponding author: Gustavo Teixeira Grottone. Avenida Almirante Cochrane 29/202 - Santos SP - 11040-001 - Brazil - E-mail: ggrottone@gmail.com 


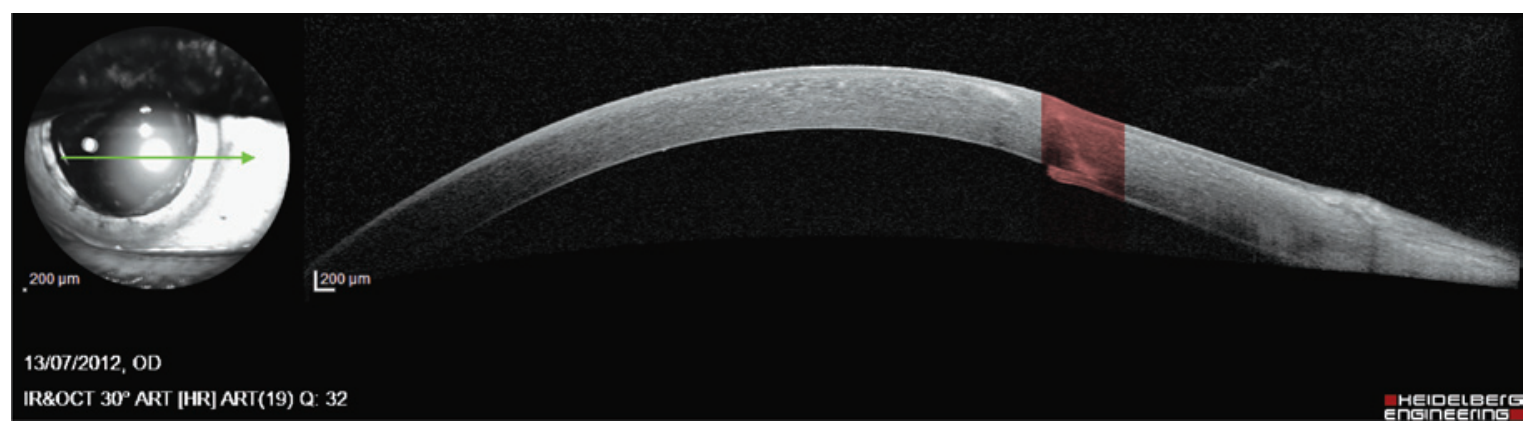

Figure 1. Optical Coherence tomography of penetrating keratoplasty showing the interface (in red) between host cornea and donor cornea.

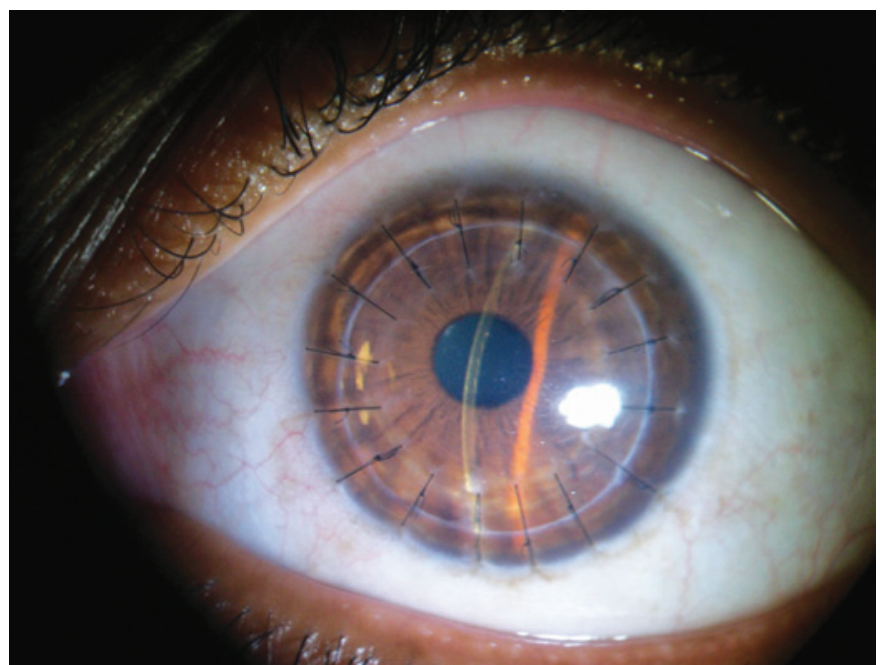

Figure 2. Slit-lamp photography of 1-month follow-up penetrating keratoplasty.

induced irregular astigmatism were major problems and limited its adoption. After this initial attempt to replace PK as the treatment for corneal endothelial cell failure, almost 40 years passed until further changes were made.

\section{Posterior lamellar keratoplasty (PLK): Changing the concepts}

A major breakthrough occurred in 1998 when Gerrit Melles described a surgical technique of PLK to selectively replace diseased endothelium while leaving the recipient anterior cornea intact ${ }^{(7)}$. A recipient posterior lamella with posterior stroma, Descemet's membrane and endothelium was dissected through a $9 \mathrm{~mm}$ sclerocorneal incision. A donor button with posterior stroma, Descemet's membrane and endothelium was inserted and successfully held in place by an air bubble with the patient in supine position ${ }^{(8)}$. Mark Terry introduced the procedure in the USA as deep lamellar endothelial keratoplasty $(\mathrm{DLEK})^{(9)}$.

After the initial results with the $9 \mathrm{~mm}$ incision technique, Melles et al. published a case report of PLK using a $5 \mathrm{~mm}$ incision and folding the donor disc to enable insertion ${ }^{(10)}$. After that, Terry described smallincision DLEK using a $5 \mathrm{~mm}$ incision in a prospective clinical study ${ }^{(11)}$. The best spectacle-corrected visual acuity (BSCVA) improved from an average of approximately 20/90 preop to approximately 20/44 at 6 months postop, with $56 \%$ of the patients $20 / 40$ or better ${ }^{(11)}$. Astigmatism by manifest refraction increased from an average of 0.86 diopters preop to an average of 1.31 diopters at 6 months, an increase of less than 0.5 diopters.

It was the first successful implementation of EK, and had clear advantages over PK because there were no anterior corneal inci- sions or sutures. It was associated with a recovery time of less than 6 months; most patients made a good visual recovery with a predictable cylindrical correction(11). There were no ocular surface or suturerelated complications and the technique had better postoperative globe integrity. However, the need to manually dissect the donor and host stroma was time-intensive and technically challenging, making adoption by surgeons very slow. Haze induction and high-order aberrations also contributed to low vision after DLEK surgery ${ }^{(12)}$.

\section{Selective Descemet's transplantation}

Four years into the era of modern endothelial keratoplasty, Melles introduced the Descemet's stripping technique(13). In 2002, consistent results were obtained in 15 cadaveric eyes; Descemet's membrane with its endothelial monolayer was stripped from the posterior stroma, obtaining a "Descemet roll". The complex was successfully implanted after "Descemetorhexis" to remove the recipient endothelial layer and its Descemet's membrane, and held in place with the aid of air bubbling ${ }^{(13)}$. The difficulties in preparing and handling a donor consisting only of Descemet's membrane and endothelium prevented this technique from being used in patients at that time. After 2 years, in 2004, Melles et al. published his previous Descemetorhexis technique (Figure 3) to prepare the recipient bed for implantation of a manually dissected donor lamellar button with posterior stroma. The recipient stripping procedure was successful in all 10 human eye bank corneas tested and 3 Fuchs dystrophy patients, and proved to be reproducible, quick and easy to perform ${ }^{(14)}$.

\section{DESCEMET'S STRIPPING ENDOTHELIAL KERATOPLASTY (DSEK): A NEW DEVELOPMENT}

After the early outstanding achievements with DLEK, this new technique involving the selective removal of the host Descemet's membrane and endothelium became more rapidly adopted. Eliminating the need for manual lamellar dissection of the host tissue made the surgical technique easier and more reproducible. Preparation and introduction of the donor lamella via a $5 \mathrm{~mm}$-long scleral pocket incision remained the same as in previous EK techniques. In 2005, Price introduced DSEK and showed that, as early as 6 months after surgery, 31 of 50 eyes (62\%) had best corrected visual acuity (BCVA) values better than 20/40 and 38 (76\%) eyes had values better than $20 / 50^{(15)}$. Importantly, refractive errors were eliminated. The mean manifest cylinder was $1.50 \pm 0.94$ diopters (D) 6 months after surgery, which was unchanged from the preoperative value of $1.5 \pm 1.0 \mathrm{D}$

Manual dissection of donor tissue with precision and consistency was challenging and time consuming. The use of a microkeratome, described in 2006 by Gorovoy ${ }^{(16)}$, greatly simplified this difficult step in DSEK surgery that became known as Descemet-stripping automated endothelial keratoplasty (DSAEK). Price et al. compared DSEK and DSAEK and found a reduced risk of donor tissue perforation and faster 
visual recovery with DSAEK (Figures 4 and 5), with the same visual results after 3 months ${ }^{(17)}$. Eye banks also started providing precut tissue for DSAEK, making it even easier for corneal surgeons. Terry et al. demonstrated that precut tissue from eye banks for use in DSAEK surgery provides cell loss and visual results comparable with reports involving tissue cut intraoperatively ${ }^{(18)}$

A recent meta-analysis ${ }^{(19)}$ of reports on DSEK/DSAEK surgery found that the most common complications were posterior graft dislocation (mean, 14\%; range, 0-82\%), endothelial graft rejection (mean, 10\%; range, 0-45\%), primary graft failure (mean, 5\%; range, 0-29\%), and iatrogenic glaucoma (mean, 3\%; range, 0-15\%). Average endothelial cell loss ranged from $25-54 \%$ with a mean cell loss of $37 \%$ at 6 months postoperative, whereas the average loss was $42 \%$ at 12 months. BCVA varied between 20/34 and 20/66 (measured at a mean of 9 months postoperative; range, 3-21 months). The extent of induced hyperopia was 0.7-1.5 D (mean, 1.1 D). Induced astigmatism was minimal, ranging from -0.4 to $0.6 \mathrm{D}$; the mean refractive shift was $0.11 \mathrm{D}$.

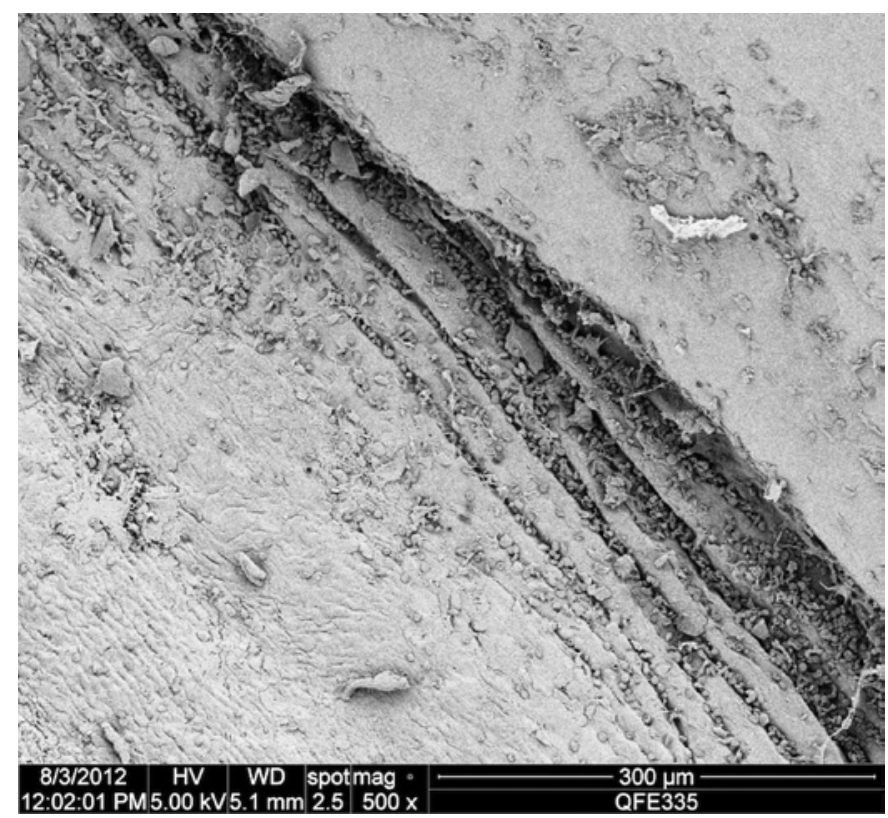

Figure 3.Scanning electron microscopy of nude stromal/Descemet's membrane interface after Descemet's stripping (500x magnification).
Remarkably, Mark Terry was able to modify some of the major steps in DSEK/DSAEK surgery, achieving highly reproducible results ${ }^{(20)}$. Using peripheral recipient bed scraping to ensure donor edge adherence and a residual supportive air bubble, the graft dislocation rate was only $1.5 \%$ when 200 consecutive cases were reviewed. This technique allowed well-supervised novice fellows to obtain results very similar to those achieved by the more experienced ${ }^{(21)}$.

The use of donor tissues $8.5 \mathrm{~mm}$ and $8.0 \mathrm{~mm}$ in diameter yielded identical endothelial cell density (ECD) results after 2 years in a prospective study ${ }^{(22,23)}$. The length of eye bank corneal storage (1 day vs. the standard storage time of $7 \mathrm{~d}$ ) had no effect on postoperative ECD, demonstrating that it is unnecessary to request eye banks to freshly prepare tissue when DSEK/DSAEK surgery is planned ${ }^{(24)}$. Also, the widespread adoption of DSAEK revealed that the use of flawed anterior stromal donor corneas, that were unsuitable for use in PK, yielded results similar to those afforded by employment of standard tissue, when the eyes were evaluated 1 year postoperative ${ }^{(25)}$

Although the cornea enjoys relative immune privilege, allograft rejection remains the leading cause of endothelial failure in several reported series of PK patients ${ }^{(26,27)}$. It was expected that DSEK/DSAEK would lower the rates of graft rejection. In a large series of 598 DSEK cases, the cumulative probability of rejection was $12 \%$ at 2 years ${ }^{(28)}$. A group of PK patients treated with the same postoperative corticoid regimen had a probability of $18 \%{ }^{(29)}$. The probability of a graft rejection episode tended to be lower after EK compared with PK, although the difference was not statistically significant ( $p=0.38)$.

Concerned about long-term graft survival after DSAEK, Mark Gorovoy collected data on corneal transparency and graft failure in 51 patients over 5 years of follow-up; 47 corneas were clear at the conclusion of the study. Thus, only four eyes developed corneal opacity due to graft failure and all eyes were successfully regrafted ${ }^{(29)}$.

Surgical correction of residual refractive errors after DSAEK was studied by Ratanasit and Gorovoy ${ }^{(30)}$, who treated three eyes with LASIK, and two with photorefractive keratoplasty (PRK) 11-17 months after DSAEK. Uncorrected visual acuity ranged from 20/80 to 20/200 before refractive surgery to 20/20 to 20/40 thereafter, whereas BCVA remained unchanged, ranging from 20/20 to 20/30.

Although the visual acuity outcomes were good, considerable cell loss in the early postoperative period remained evident, and the need to improve insertion techniques became important. A 2009 study compared forceps insertion with the use of pull-through techniques ${ }^{(31)}$. Also, lenticule folding and unfolding during insertion were examined. The extent of cell loss after the use of pull-through and forceps insertion techniques was not significantly different when the incision was $5 \mathrm{~mm}$ long. The results suggested that the smaller the incision the greater the injury ${ }^{(31)}$. Another study showed that ECD 6 months after use of a Busin-glide system were slightly better than

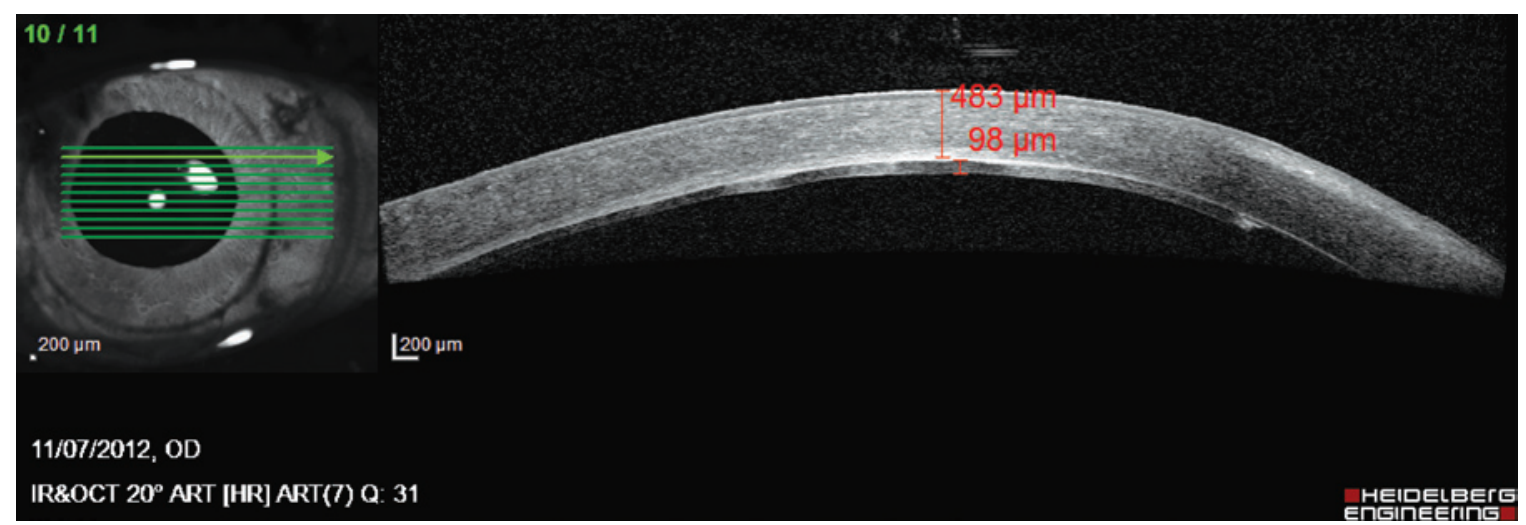

Figure 4. Optical coherence tomography of DSEK surgery showing the interface between the host cornea and donor endothelial/Descemet's membrane complex. 
were those seen when forceps insertion was employed ${ }^{(32)}$. A new device (the EndoGlide ${ }^{\mathrm{TM}}$ ) was compared with the Busin-glide; endothelial cell loss was much lower in patients treated using the EndoGlide $(25.76 \%)$ than in those treated employing the Busin-glide $(47.46 \%$; $P<0.0001)$. Visual acuity values and refractive changes were similar in either group ${ }^{(33)}$. In Brazil, Pazos et al. showed that ECD 6 months after surgery ranged from 1,305 cells $/ \mathrm{mm}^{2}$ to 2,346 cells $/ \mathrm{mm}^{2}$; the extent of cell loss was $33.14 \% \%^{(34)}$

\section{DMEK: REVISITING THE USE OF Descemet's MEMBRANE}

Although DSAEK yields excellent and reproducible results, the search for complete visual rehabilitation and restoration of the natural corneal anatomy continued. Melles et al. analyzed data from his own work in selective Descemet's transplantation ${ }^{(11,12)}$, solved several major issues, and introduced a new technique termed Descemet's

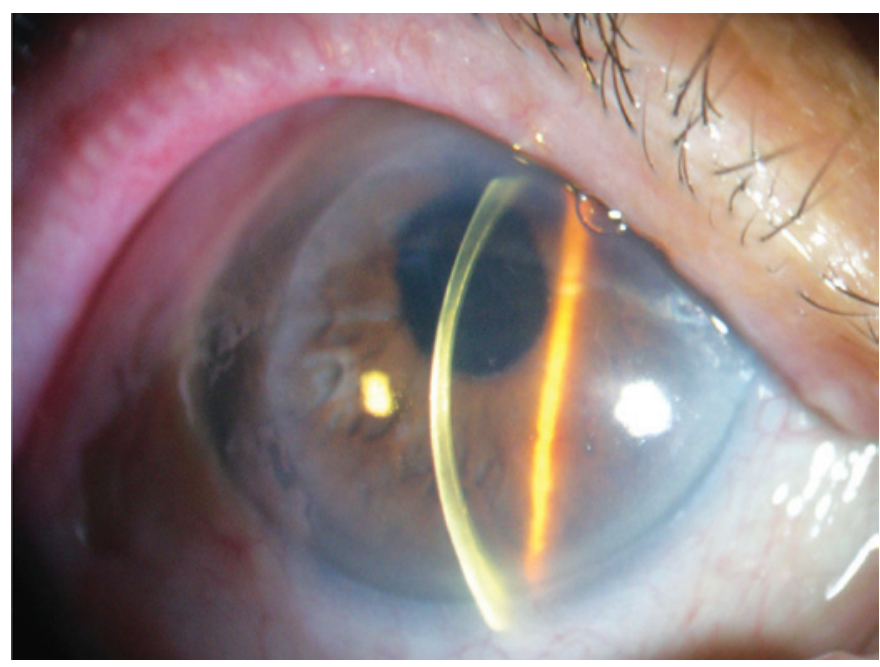

Figure 5. Slit-lamp photography of 1-month follow-up Descemet's stripping automated endothelial keratoplasty from the patient above (fellow eye Figure1).

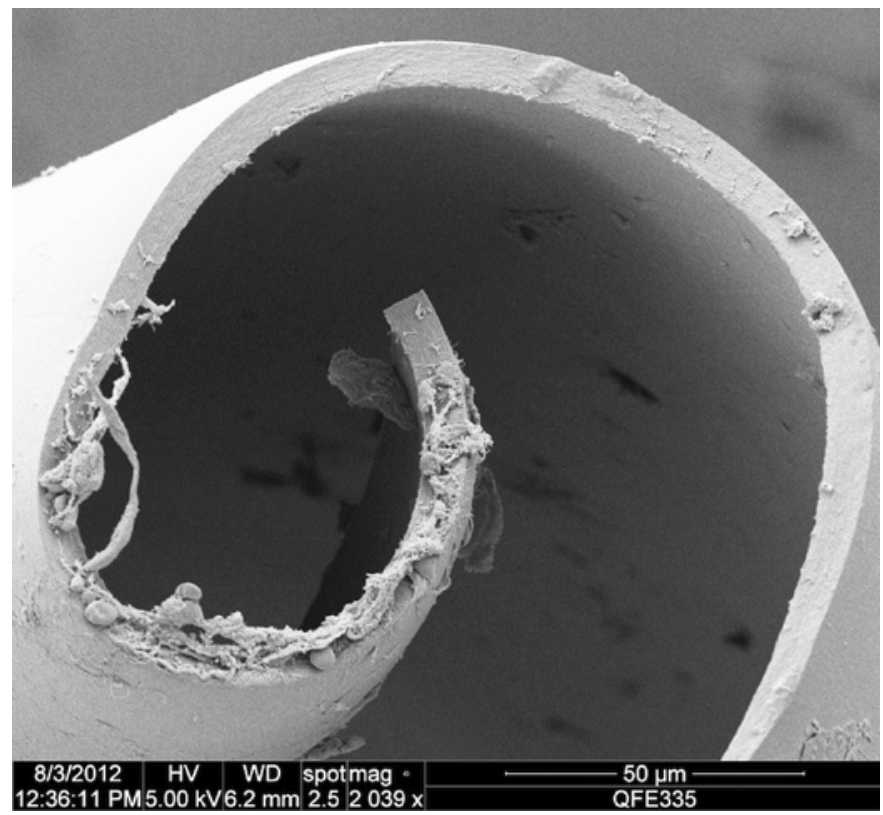

Figure 6. Scanning electron microscopy of stripped Descemet's/endothelial sheet on DMEK procedure (2000x magnification). membrane endothelial keratoplasty (DMEK) ${ }^{(35)}$. In this approach, donor endothelial cells carried on Descemet's membranes stripped (Figure 6) from donor corneas are inserted into the host anterior chamber via a $3 \mathrm{~mm}$ incision in the clear cornea. The donor is unrolled using an air-filling technique and the graft incorporated in the posterior cornea in a manner similar to that employed by earlier endothelial keratoplasties (Figure 7) ${ }^{(35)}$. Preliminary results showed that this revisited technique not only reproduced the results achieved with DSEK/DSAEK, but exceeded visual acuity expectations. Of an initial 7 successful DMEK eyes, 6 had BCVA values of 0.5 (20/40) or better, and 3 eyes attained $1.0(20 / 20)^{(35)}$. ECD at 6 months declined to a level comparable to that seen when other EK techniques are employed ${ }^{(35)}$. Next, the same group obtained extensive data on 50 patients ${ }^{(36)}$. Of 40 eyes successfully treated with DMEK, $95 \%$ had BCVA values of $20 / 40$ or better and $75 \%$ had values of $20 / 25$ or better at the 6 -month follow-up. Again, the extent of endothelial cell loss was similar to that seen when other EK techniques are employed ${ }^{(36)}$.

Soon thereafter, Price et al. reported on a prospective study with a 3-month follow-up ${ }^{(37)}$. Of an initial 60 eyes, $26 \%$ attained a BCVA of $20 / 20,63 \%$ a BCVA of 20/25 or better, and $94 \%$ a BCVA of 20/40 or better. The refractive cylinder was sustained and the hyperopic shift was 0.49-0.63 D ( $P=0.0091)$. Endothelial cell loss was $30 \pm 20 \%$ at 3 months and $32 \pm 20 \%$ in 38 eyes examined at 6 months. Five DMEK corneas (8\%) failed to clear; the patients were treated again with DMEK or DSAEK ${ }^{(37)}$.

Initial endothelial cell counts have been comparable to DSAEK. An average ECD of 1,850 cells $/ \mathrm{mm}^{2}$ at 6 months and 1,680 cells $/ \mathrm{mm}^{2}$ at 12 months after surgery was reported by Melles group ${ }^{(38)}$. The Price group reported a mean ECD of 1,911 \pm 593 cells $/ \mathrm{mm}^{2}$ at 12 months after surgery, representing a mean cell loss of $36 \pm 20 \%$ (39).

It was expected that DMEK would provide even lower rates of graft rejection. The initial reports were surprisingly low, with the Melles group showing a rejection rate of $\leq 1 \%$ despite the use of large-diameter donor tissue ${ }^{(40)}$. Anshu et al. ${ }^{(41)}$ compared the cumulative probability of rejection after PK, DSEK, and DMEK, using the same postoperative corticoid regimen. The Kaplan-Meier estimated probability of graft rejection was $1 \%$ for DMEK, $12 \%$ for DSEK, and $18 \%$ for PK at 2 years after grafting. Thus, the DMEK eyes had a 15 fold lower risk of rejection than DSEK eyes and 20 fold lower risk than PK eyes ${ }^{(41)}$.

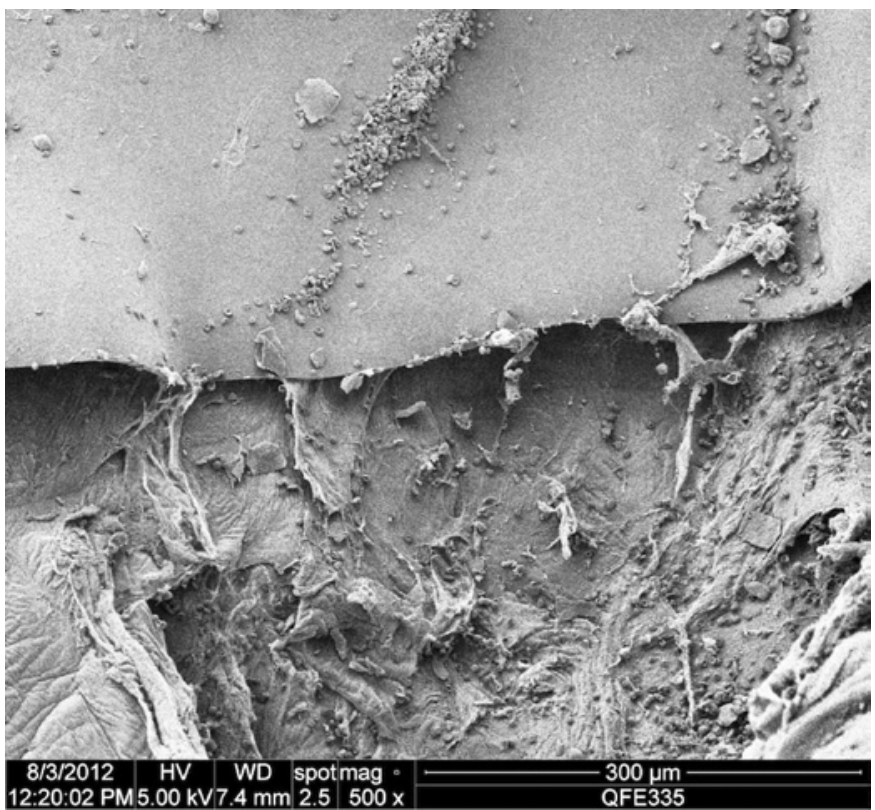

Figure 7.Scanning electron microscopy of DMEK graft with residual folds at endothelial/ stroma interface (500x magnification). 
Graft detachment and primary graft failure are the main concerns after DMEK. In the preliminary results of the first 10 DMEK cases, 3 eyes showed a complete detachment that was managed by removal of the transplant and a secondary DSEK ${ }^{(35)}$. In the review of the first 50 consecutive cases from the Melles group, ten patients (20\%) required a secondary DSEK for failed DMEK ${ }^{(36)}$. A prospective study with 60 patients showed 8\% failures that were treated with a secondary DSAEK or DMEK ${ }^{(37)}$. When evaluating the learning curve in the first 135 cases, Melles group found a primary graft failure rate of only $2.2 \%$ after the initial learning curve ${ }^{(42)}$. In 2010, Dapena et al. (from Melles group) explored how a secondary DSEK surgery (after failed DMEK) affected visual acuity ${ }^{(43)}$. Eighty-seven percent of patients had a BCVA of 20/40 or better, and one eye reached 20/25, 6 months after surgery ${ }^{(43)}$. The ECD fell from $2,617 \pm 152$ cells $/ \mathrm{mm}^{2}$ before surgery to $1,602 \pm 892$ cells $/ \mathrm{mm}^{2}$ at the 12 -month followup ${ }^{(43)}$ The work suggested that the surgeon and the patient should both be aware that a secondary DSEK may be required after a DMEK graft failure. Particularly during the learning curve, patient information may be provided not only after DMEK, but also after DSEK. After the back-up surgery, good visual acuity levels were achieved, similar to those after a primary DSEK, although these were slightly inferior to what would be expected after DMEK ${ }^{(43)}$. The evaluation of the learning curve in DMEK revealed a direct correlation between graft detachment and surgeon experience ${ }^{(44)}$. The detachment rate declined from $20 \%$ over the first 45 surgical procedures to less than $4.4 \%$ thereafter ${ }^{(44)}$. Intraoperative vitreous pressure was identified as an important risk factor for graft detachment in different publications $(35,36,43,44)$.

In 2011, Dirisamer et al. explored the importance of surpassing the learning curve with DMEK to achieve a low complication rate ${ }^{(44)}$. After a learning curve of 25 cases, 5\% to 9\% partial graft detachment was the most frequent complication in 200 cases. After the learning curve with DMEK, it is possible to achieve a low complication rate and ECD comparable to DSAEK with faster and better visual recovery ${ }^{(43,44)}$

\section{HybRID TECHNIQUES: JOINING DMEK AND DSAEK}

The literature indicates that ECD is similarly affected by DMEK and DSAEK. However, DMEK is associated with better BCVA outcomes and faster visual rehabilitation than those yielded by DSAEK. Transplanting posterior stroma results in worse visual outcomes compared to selective Descemet's membrane and endothelium transplantation ${ }^{(45)}$

Trying to offer better visual results, the DSAEK enthusiast Massimo Busin created a variant of DSAEK termed Ultra-Thin DSAEK, which reduced the thickness of the donor stromal tissue by approximately half(46). A microkeratome was used to make two cuts to controlled depths with the aid of a pachymeter in 40 donor tissues. This additional manipulation did not appear to cause extra endothelial damage ${ }^{(46)}$. Tissue preparation with a double-pass microkeratome can increase the risk of perforation and tissue loss ${ }^{(47)}$. Some reports show better visual results with thinner grafts ${ }^{(48)}$, but others show no difference from regular DSAEK grafts ${ }^{(17,18,49)}$. There is no consensus that thinner grafts provide better and faster visual rehabilitation.

Trying to merge DMEK superior visual results with the easier manipulation of the DSAEK grafts, in 2009 McCauley et al. described a hybrid DSAEK/DMEK technique, using big-bubble dissection at the central part of the donor cornea, to leave a bare central Descemet's membrane with a peripheral rim of stroma ${ }^{(50)}$. The main challenge is the donor preparation, with higher risk for losing the graft than with DSAEK ${ }^{(50)}$. This report was followed by an article by Busin showing that insertion and manipulation of Descemet's membrane with a stromal peripheral support was easier than a regular DMEK graft; the BCVA and hyperopic shift outcomes were very similar to those seen after DMEK ${ }^{(51)}$.

\section{Pure endothelial Keratoplasty (PEK): the future}

In 2000, a new direction for endothelial keratoplasty emerged when Nancy Joyce discovered that human corneal endothelial cells
(HCECS) could proliferate and replicate under special conditions. Using a combination of growth factors (EGF, FGF, and PDGF) and fetal bovine serum enabled corneas maintained in culture to express the Ki-67 protein, a cellular marker for proliferation. Donor age influenced the extent of replication, but even older donor tissue entered the cell cycle ${ }^{(52)}$. In the same year, it was shown that disruption of cell-cell contact was essential for endothelial cells to enter the active cell cycle. EDTA facilitates cell-cell disruption by sequestering calcium (which is essential for cell-cell binding). Treatment with EDTA $(2.0 \mathrm{mg} / \mathrm{ml})$ for 1 hour stimulated $16-18 \%$ of corneal cells to proliferate. This was confirmed by expression of Ki-67 and ZO-1 markers by both the proliferating cells and daughter cells thereof. Also, the use of EDTA alone, rather than a trypsin/EDTA solution to digest cells, afforded a good cell survival rate ${ }^{(53)}$. In agreement with these data, Zhu showed more recently that a group of cadherins and catenins is responsible for cell cycle arrest in HCECs. This result supports the hypothesis that retention of cells in culture for a long time without disruption of cell-cell attachment eventually causes the cells to "hibernate" in terms of cell cycle activity ${ }^{(54)}$. Another report indicated that younger donors should preferably serve as cell sources if endothelial proliferation is desired ${ }^{(55)}$. Further, it was shown that removal of HCECs in the presence of an intact Descemet's membrane avoided potential contamination with other cell types ${ }^{(56)}$.

New and valuable information was afforded by several studies that took the work in previously unexplored directions. One great concern has been how to deploy endothelial cells in a manner in which the cells do not disperse in the anterior chamber. The first approach employed magnetic attraction. In two important reports, Mimura et al. showed that it was possible to have rabbit corneal endothelial cells (RCECs) incorporate iron powder spheres. After titrating the toxicity of the iron particles, it was apparent that the use of 5-10 micromoles of iron powder solution was associated with good cell survival rate. After preparation as a single-cell suspension, RCECs were injected into the anterior chamber of the rabbit eye and a neodymium magnet was placed anterior to the eyelid. The treated animals recovered corneal transparency within 8 weeks. The control group showed clinical features of endothelial failure(57). Although data obtained with RCECs are of limited use, since they can regenerate spontaneously, the study identified a new method by which endothelial cells can be manipulated and deployed at the posterior surface of the cornea. Two years later, the same group reported the 12-month data; no noticeable toxicity was evident in any animals from the preliminary study according to ERG, ECD, and clinical ocular findings ${ }^{(58)}$. However, the effects of iron particles on human eyes remain unknown.

In 2005, three reports furthered corneal endothelial cell therapies. It was shown that HCECs isolated from donor corneas and incubated in a methylcellulose matrix aggregated in a manner resembling neurospheres ${ }^{(59)}$. The spheres had a high proliferative capacity and were capable of repopulating the posterior cornea of rabbits after injection, with the animals held in the prone position for 24 hours ${ }^{(60)}$. In a later report, the time required in the prone position (to ensure cell adherence) was reduced from 24 hours to 6 hours, rendering it easier to consider human applications of such treatment ${ }^{(61)}$.

An important aspect of corneal endothelial therapies is the method used to harvest endothelial cells. At one point, EDTA treatment, trypsin, dispase, and various mechanical methods have all been employed. Problems with all these methods include yield variability, the need to coat culture dishes with extracellular matrix (ECM), and toxicity. A novel method for isolating such cells was suggested by Li et al. in 2007(62); the usual methods were compared with collagenase A digestion. The latter method allowed collection of consistently round cell aggregates resulting from digestion of Descemet's membrane and endothelial cells. The attraction of using collagenase A rather than dispase or EDTA is that most of the ECM required for cell adhesion to culture dishes is already associated with the cell aggregates. 
Additionally, the cell survival rate was far superior to that when the earlier methods were used, possibly because cell-cell interaction was sustained during Descemet's membrane digestion (Figure 8). It was also shown that brief washing of cell aggregates with EDTA $(0.02 \%$, $\mathrm{W} / \mathrm{V}$ ) afforded consistent levels of cell proliferation and migration ${ }^{(62)}$.

A 2009 report ${ }^{(63)}$ revisited the earlier ideas of Mimura. The cited work tested superparamagnetic iron-oxide nanoparticles (SPIOs) of different sizes and with various coatings, using the same internalization concept, and titrated the dose, toxicity, and extent of magnetic attraction. The fact that such compounds are already available as MRI contrast agents, on which safety and efficacy studies have been conducted, suggested that cell delivery using such compounds would be safer than employing the iron powder used in older studies. The SPIOs showed good tolerability and low toxicity at the concentrations tested. Smaller SPIOs exhibited dose-dependent incorporation into the cytoplasm of human endothelial cells; such cells were readily attracted to a magnetic field and were capable of integration and migration to the posterior surfaces of corneas mounted in an artificial chamber.

The effects of cyclin-dependent kinase inhibitors including p21Cip1, p16INK4a, and p27Kip1 on G1-phase arrest of HCECs have been explored. In 2006, Kikuchi showed that a dose-dependent decrease in the p27kip1 protein level was evident after transfection of HCECs with a p27kip1-silencing small interfering RNA (siRNA). The numbers of HCECs from young donors transfected with p27kip1 siRNA increased up to 144 hours after incubation, No change in cells transfected with non-silencing siRNA was observed. On the other hand, no change in cell number was observed when HCECs from older donors were studied, suggesting that G1-phase inhibition is mediated in a different manner in older subjects ${ }^{(64)}$.

Joyce et al. ${ }^{(65)}$ explored the mechanism of G1-phase arrest in HCECs from older patients. The roles played by p21Cip1 and p16INK4a in negative regulation of the cell cycle in such cells were clarified. The number of cells from older donors entering the cell cycle after transient silencing using p21Cip1- and p16INK4a-siRNA was, on average, $65 \%$ after Day 1 ( $19 \%$ in controls) ( $P=0.03$ ). Also, the total cell number in the p $21+p 16$ siRNA-treated group rose 2.6 -fold; the control value was only 1.1 -fold ${ }^{(65)}$.

In addition, work dating from 2006 suggested that p21Cip1 and p27Kip 1 expression levels could be altered via the action of a specific protein. The Rho GTPase protein (containing RhoA and RhoC) regulates numerous effector proteins; a vital signaling role is played by the ROCK I and ROCK II serine/threonine kinases. The use of the selective ROCK I inhibitor Y27632 downregulated the mitogen-activated pro-

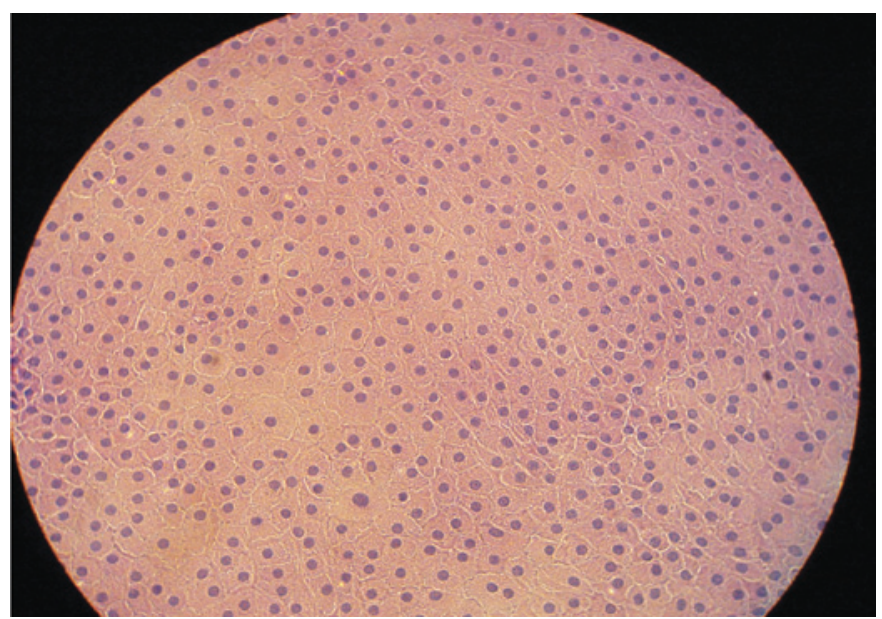

Figure 8. Photomicroscopy of primary culture of human corneal endothelial cells cultured for 4 weeks (magnification 20x - HE stain). tein kinase pathway, increased cyclin A levels via activation of LIM kinase 2, and reduced p27Kip1 protein levels ${ }^{(66)}$. In line with these findings, Okumura et al. ${ }^{(67)}$ used a ROCK I-selective inhibitor to enhance the adhesion and proliferation of monkey corneal endothelial cells (MCECs). After 3 days, untreated MCECs were proliferating and were enlarged, but were not confluent or homogeneously hexagonal. Y-27632-treated MCECs exhibited a confluent monolayer of homogeneously hexagonal cells of smaller size. After 10 days, MCECs treated with Y-27632 yielded colony areas 1.6-fold more extensive $(P=0.01)$ than those of control cells ${ }^{(67)}$. A similar effect was evident both in vitro and in vivo upon instillation of Y-27632-containing eye drops six times daily for a week ${ }^{(68-70)}$. Recently, the same group successfully injected a single-cell suspension into the anterior chamber of monkey eyes, to restore the corneal endothelial layer. Cells exposed to Y-27632 exhibited good adhesion and survival after animals were restrained for 3 hours in the head-prone position. Cells not exposed to Y-27632 did not attach to posterior stromal tissue ${ }^{(70)}$.

Immortalization of corneal endothelial cells has been attempted in several ways, including via transfection of the SV40 oncogene ${ }^{(71)}$, retroviral transduction of genes encoding papilloma-virus E6/E7 or Cdk4R24C/CyclinD1, and spontaneous immortalization (72,73)

Some clinical practice reports have come to the same conclusion reached in the preclinical work. In 2009, two cases of spontaneous corneal clearance after subtotal DMEK graft detachment were reported. The patients attained a BCVA of 20/28 and 20/20 after 9 months ${ }^{(74)}$. Similar results were noted in 28 of 36 eyes from patients after stromal gap or subtotal graft detachment. Re-establishment of the endothelium proceeded in an inverse manner in those with subtotal graft detachments, suggesting massive migration of corneal endothelial cells from the graft to the host cornea, and from the periphery to the center ${ }^{(75)}$. In 2012, the Melles group described what they termed "Descemet's membrane endothelial transfer" in a patient in whom a graft was free-floating in the anterior chamber. Corneal clearance was achieved after some months, exhibiting re-endothelialization of the recipient posterior stroma and suggesting the potential for a "no-keratoplasty" surgical concept in the management of corneal endothelial disorders ${ }^{(76)}$.

\section{CONCLUSIONS}

EK is an evolving treatment that represents a great improvement on PK. During the last 10 years, EK has been shown to be safe and effective when used to treat endothelial dysfunction. DSEK and DSAEK are the surgical techniques most employed today, and yield good results, although DMEK offers advantages in terms of postoperative visual results and graft rejection rates. The use of DMEK and hybrid techniques is increasing and may overcome DSAEK worldwide within a few years. The future of EK is dependent on advances in pure endothelial keratoplasty. A collaborative translational effort must be made to render endothelial cell therapy a viable treatment alternative. Preclinical studies have yielded sufficient data to make it clear that pure endothelial keratoplasty will become possible in time.

\section{ACKNOWLEDGEMENTS}

We gratefully acknowledge the assistance of Mr. André Aguillera, Ms. Márcia Tanakai and Ms. Patrícia Milanez for their expertise in electron microscopy and contributing their valuable images this paper.

\section{REFERENCES}

1. Aiken-O'Neill P, Mannis MJ. Summary of corneal transplant activity Eye Bank Association of America. Cornea. 2002;21(1):1-3.

2. Flores VG, Dias HL, Castro RS. Indicações para ceratoplastia penetrante no Hospital das Clínicas-UNICAMP. Arq Bras Oftalmol. 2007;70(3):505-8.

3. Eye Bank Association of America. 2011 Eye banking statistical report [Internet] 2005/04/20 ed. Washington DC: Available from: http://www.corneas.org/repository/ images/pressimages/EBAA 2011 Statistical Report - Final.pdf 
4. Li JY, Mannis MJ. Eye banking and the changing trends in contemporary corneal surgery. Int Ophthalmol Clin. 2010;50(3):101-12.

5. Eye Bank Association of America. 2009 Eye banking statistical report [Internet] Washington DC: Available from: http://www.corneas.org/repository/images/pressimages/EBAA 2009 Statistical Report - Final.pdf

6. Culbertson WW. Endothelial replacement: flap approach. Ophthalmol Clin North Am 2003:16(1):113-8, vii.

7. Melles GR, Eggink FA, Lander F, Pels E, Rietveld FJ, Beekhuis WH, et al. A surgical technique for posterior lamellar keratoplasty. Cornea. 1998;17(6):618-26.

8. Melles GR, Lander F, Beekhuis WH, Remeijer L, Binder PS. Posterior lamellar keratoplasty for a case of pseudophakic bullous keratopathy. Am J Ophthalmol. 1999; 127(3):340-1.

9. Terry MA, Ousley PJ. Deep lamellar endothelial keratoplasty in the first United States patients: early clinical results. Cornea. 2001;20(3):239-43.

10. Melles GR, Lander F, Nieuwendaal C. Sutureless, posterior lamellar keratoplasty: a case report of a modified technique. Cornea. 2002;21(3):325-7.

11. Terry MA, Ousley PJ. Small-incision deep lamellar endothelial keratoplasty (DLEK): six-month results in the first prospective clinical study. Cornea. 2005;24(1):59-65

12. Hindman HB, McCally RL, Myrowitz E, Terry MA, Stark WJ, Weinberg RS, et al. Evaluation of deep lamellar endothelial keratoplasty surgery using scatterometry and wavefront analyses. Ophthalmology. 2007;114(11):2006-12.

13. Melles GR, Lander F, Rietveld FJ. Transplantation of Descemet's membrane carrying viable endothelium through a small scleral incision. Cornea. 2002;21(4):415-8

14. Melles GR, Wijdh RH, Nieuwendaal CP. A technique to excise the Descemet membrane from a recipient cornea (descemetorhexis). Cornea. 2004:23(3):286-8.

15. Price FW Jr, Price MO. Descemet's stripping with endothelial keratoplasty in 50 eyes: a refractive neutral corneal transplant. J Refract Surg. 2005;21(4):339-45.

16. Gorovoy MS. Descemet-stripping automated endothelial keratoplasty. Cornea. 2006;25(8):886-9. Comment in Cornea. 2006;25(8):879-81.

17. Price MO, Price FW Jr. Descemet's stripping with endothelial keratoplasty: comparative outcomes with microkeratome-dissected and manually dissected donor tissue. Ophthalmology. 2006;113(11):1936-42.

18. Terry MA, Shamie N, Chen ES, Phillips PM, Hoar KL, Friend DJ. Precut tissue for Descemet's stripping automated endothelial keratoplasty: vision, astigmatism, and endothelial survival. Ophthalmology. 2009:116(2):248-56.

19. Lee WB, Jacobs DS, Musch DC, Kaufman SC, Reinhart WJ, Shtein RM. Descemet's stripping endothelial keratoplasty: safety and outcomes: a report by the American Academy of Ophthalmology. Ophthalmology. 2009:116(9):1818-30.

20. Terry MA, Shamie N, Chen ES, Hoar KL, Friend DJ. Endothelial keratoplasty a simplified technique to minimize graft dislocation, iatrogenic graft failure, and pupillary block. Ophthalmology. 2008;115(7):1179-86

21. Chen ES, Terry MA, Shamie N, Hoar KL, Phillips PM, Friend DJ. Endothelial keratoplasty: vision, endothelial survival, and complications in a comparative case series of fellows vs attending surgeons. Am J Ophthalmol. 2009;148(1):26-31.e2.

22. Price MO, Price FW Jr. Endothelial cell loss after descemet stripping with endothelia keratoplasty influencing factors and 2-year trend. Ophthalmology. 2008;115(5):857-65. Comment in Ophthalmology. 2009;116(3):367-8

23. Terry MA, Li J, Goshe J, Davis-Boozer D. Endothelial keratoplasty: the relationship between donor tissue size and donor endothelial survival. Ophthalmology. 2011 118(10):1944-9.

24. Terry MA, Shamie N, Straiko MD, Friend DJ, Davis-Boozer D. Endothelial keratoplasty: the relationship between donor tissue storage time and donor endothelial survival. Ophthalmology. 2011;118(1):36-40

25. Phillips PM, Terry MA, Shamie N, Chen ES, Hoar KL, Stoeger C, et al. Descemet's stripping automated endothelial keratoplasty (DSAEK) using corneal donor tissue not acceptable for use in penetrating keratoplasty as a result of anterior stromal scars, pterygia, and previous corneal refractive surgical procedures. Cornea. 2009;28(8):871-6.

26. Tan DT, Janardhanan $\mathrm{P}$, Zhou $\mathrm{H}$, Chan $\mathrm{YH}$, Htoon HM, Ang LP, et al. Penetrating keratoplasty in Asian eyes: the Singapore Corneal Transplant Study. Ophthalmology. 2008;115(6):975-82.e1

27. Price MO, Thompson RW Jr, Price FW Jr. Risk factors for various causes of failure in initial corneal grafts. Arch Ophthalmol. 2003;121(8):1087-92.

28. Price MO, Jordan CS, Moore G, Price FW Jr. Graft rejection episodes after Descemet stripping with endothelial keratoplasty: part two: the statistical analysis of probability and risk factors. Br J Ophthalmol. 2009;93(3):391-5.

29. Ratanasit A, Gorovoy MS. Long-term results of Descemet stripping automated endothelial keratoplasty. Cornea. 2011;30(12):1414-8.

30. Ratanasit A, Gorovoy MS. Laser-assisted in situ keratomileusis or photorefractive keratectomy after Descemet stripping automated endothelial keratoplasty. Cornea. 2011:30(7):787-9.

31. Terry MA, Saad HA, Shamie N, Chen ES, Phillips PM, Friend DJ, et al. Endothelial keratoplasty: the influence of insertion techniques and incision size on donor endothelial survival. Cornea. 2009;28(1):24-31

32. Bahar I, Kaiserman I, Sansanayudh W, Levinger E, Rootman DS. Busin Guide vs Forceps for the Insertion of the Donor Lenticule in Descemet Stripping Automated Endothelial Keratoplasty. Am J Ophthalmol. 2009;147(2):220-6.e1. Comment in Am J Ophthalmol. 2009;148(1):175; author reply 175-6.
33. Gangwani V, Obi A, Hollick EJ. A prospective study comparing EndoGlide and Busin glide insertion techniques in descemet stripping endothelial keratoplasty. Am J Ophthalmol. 2012;153(1):38-43.e1.

34. Pazos HS, Pazos PF, Nogueira Filho PA, Grisolia AB, Silva AB, Gomes JA. Ceratoplastia endotelial com desnudamento da Descemet (DSEK) utilizando o dispositivo TAN EndoGlideTM: série de casos. Arq Bras Oftalmol. 2011;74(3):195-200

35. Melles GR, Ong TS, Ververs B, van der Wees J. Preliminary clinical results of Descemet membrane endothelial keratoplasty. Am J Ophthalmol. 2008;145(2):222-7.

36. Ham L, Dapena I, van Luijk C, van der Wees J, Melles GR. Descemet membrane endothelial keratoplasty (DMEK) for Fuchs endothelial dystrophy: review of the first 50 consecutive cases. Eye (Lond). 2009;23(10):1990-8.

37. Price MO, Giebel AW, Fairchild KM, Price FW Jr. Descemet's membrane endothelial keratoplasty: prospective multicenter study of visual and refractive outcomes and endothelial survival. Ophthalmology. 2009;116(12):2361-8.

38. Ham L, van Luijk C, Dapena I, Wong TH, Birbal R, van der Wees J, et al. Endothelial cell density after descemet membrane endothelial keratoplasty: 1- to 2-year follow-up. Am J Ophthalmol. 2009:148(4):521-7.

39. Guerra FP, Anshu A, Price MO, Giebel AW, Price FW. Descemet's membrane endothelial keratoplasty: prospective study of 1-year visual outcomes, graft survival, and endothelial cell loss. Ophthalmology. 2011:118(12):2368-73.

40. Dapena I, Ham L, Netuková M, van der Wees J, Melles GR. Incidence of early allograft rejection after Descemet membrane endothelial keratoplasty. Cornea. 2011;30(12): 1341-5.

41. Anshu A, Price MO, Price FW Jr. Risk of corneal transplant rejection significantly reduced with Descemet's membrane endothelial keratoplasty. Ophthalmology. 2012; 119(3):536-40.

42. Dapena I, Ham L, Droutsas K, van Dijk K, Moutsouris K, Melles GR. Learning Curve in Descemet's Membrane Endothelial Keratoplasty: First Series of 135 Consecutive Cases. Ophthalmology. 2011;118(11):2147-54

43. Dapena I, Ham L, van Luijk C, van der Wees J, Melles GR. Back-up procedure for graft failure in Descemet membrane endothelial keratoplasty (DMEK). Br J Ophthalmol. 2010;94(2):241-4.

44. Dirisamer M, Ham L, Dapena I, Moutsouris K, Droutsas K, van Dijk K, et al. Efficacy of descemet membrane endothelial keratoplasty: clinical outcome of 200 consecutive cases after a learning curve of 25 cases. Arch Ophthalmol. 2011:129(11):1435-43.

45. Tourtas T, Laaser K, Bachmann BO, Cursiefen C, Kruse FE. Descemet membrane endothelial keratoplasty versus descemet stripping automated endothelial keratoplasty. Am J Ophthalmol. 2012;153(6):1082-90.e2.

46. Busin M, Patel AK, Scorcia V, Ponzin D. Microkeratome-assisted preparation of ultrathin grafts for Descemet stripping automated endothelial keratoplasty. Invest Ophthalmol Vis Sci. 2012;53(1):521-4

47. Sikder S, Nordgren RN, Neravetla SR, Moshirfar M. Ultra-thin donor tissue preparation for endothelial keratoplasty with a double-pass microkeratome. Am J Ophthalmol. 2011;152(2):202-8.e2.

48. Neff KD, Biber JM, Holland EJ. Comparison of central corneal graft thickness to visual acuity outcomes in endothelial keratoplasty. Cornea. 2011;30(4):388-91.

49. Nieuwendaal CP, van Velthoven ME, Biallosterski C, van der Meulen IJ, Lapid-Gortzak $\mathrm{R}$, Melles GR, et al. Thickness measurements of donor posterior disks after Descemet stripping endothelial keratoplasty with anterior segment optical coherence tomography. Cornea. 2009;28(3):298-303.

50. McCauley MB, Price FW Jr, Price MO. Descemet membrane automated endothelial keratoplasty: hybrid technique combining DSAEK stability with DMEK visual results. J Cataract Refract Surg. 2009;35(10):1659-64

51. Busin M, Patel AK, Scorcia V, Galan A, Ponzin D. Stromal support for Descemet's membrane endothelial keratoplasty. Ophthalmology. 2010;117(12):2273-7.

52. Senoo T, Joyce NC. Cell cycle kinetics in corneal endothelium from old and young donors. Invest Ophthalmol Vis Sci. 2000;41(3):660-7.

53. Senoo T, Obara Y, Joyce NC. EDTA: a promoter of proliferation in human corneal endothelium. Invest Ophthalmol Vis Sci. 2000:41(10):2930-5.

54. Zhu YT, Hayashida Y, Kheirkhah A, He H, Chen SY, Tseng SC. Characterization and comparison of intercellular adherent junctions expressed by human corneal endothelial cells in vivo and in vitro. Invest Ophthalmol Vis Sci. 2008:49(9):3879-86.

55. Miyata K, Drake J, Osakabe Y, Hosokawa Y, Hwang D, Soya K, et al. Effect of donor age on morphologic variation of cultured human corneal endothelial cells. Cornea. 2001;20(1):59-63.

56. Joyce NC, Zhu CC. Human corneal endothelial cell proliferation: potential for use in regenerative medicine. Cornea. 2004:23(8 Suppl):S8-19.

57. Mimura T, Shimomura N, Usui T, Noda Y, Kaji Y, Yamgami S, et al. Magnetic attraction of iron-endocytosed corneal endothelial cells to Descemet's membrane. Exp Eye Res. 2003;76(6):745-51.

58. Mimura T, Yamagami S, Usui T, Ishii Y, Ono K, Yokoo S, et al. Long-term outcome of iron-endocytosing cultured corneal endothelial cell transplantation with magnetic attraction. Exp Eye Res. 2005:80(2):149-57.

59. Mimura T, Yamagami S, Yokoo S, Yanagi Y, Usui T, Ono K, et al. Sphere therapy for corneal endothelium deficiency in a rabbit model. Invest Ophthalmol Vis Sci. 2005; 46(9):3128-35.

60. Mimura T, Yokoo S, Araie M, Amano S, Yamagami S. Treatment of rabbit bullous kera- 
topathy with precursors derived from cultured human corneal endothelium. Invest Ophthalmol Vis Sci. 2005;46(10):3637-44.

61. Mimura T, Yamagami S, Usui T, Seiichi, Honda N, Amano S. Necessary prone position time for human corneal endothelial precursor transplantation in a rabbit endothelial deficiency model. Curr Eye Res. 2007;32(7-8):617-23.

62. Li W, Sabater AL, Chen YT, Hayashida Y, Chen SY, He H, et al. A novel method of isolation, preservation, and expansion of human corneal endothelial cells. Invest Ophthalmol Vis Sci. 2007;48(2):614-20

63. Patel SV, Bachman LA, Hann CR, Bahler CK, Fautsch MP. Human corneal endothelial cell transplantation in a human ex vivo model. Invest Ophthalmol Vis Sci. 2009; 50(5):2123-31.

64. Kikuchi M, Zhu C, Senoo T, Obara Y, Joyce NC. p27kip1 siRNA induces proliferation in corneal endothelial cells from young but not older donors. Invest Ophthalmol Vis Sci. 2006;47(11):4803-9.

65. Joyce NC, Harris DL. Decreasing expression of the G1-phase inhibitors, p21Cip1 and p16INK4a, promotes division of corneal endothelial cells from older donors. Mol Vis. 2010;16:897-906.

66. Croft DR, Olson MF. The Rho GTPase effector ROCK regulates cyclin A, cyclin D1, and p27Kip1 levels by distinct mechanisms. Mol Cell Biol. 2006;26(12):4612-27.

67. Okumura N, Ueno M, Koizumi N, Sakamoto Y, Hirata K, Hamuro J, et al. Enhancement on primate corneal endothelial cell survival in vitro by a ROCK inhibitor. Invest Ophthalmol Vis Sci. 2009;50(8):3680-7.

68. Okumura N, Koizumi N, Ueno M, Sakamoto Y, Takahashi H, Hirata K, et al. Enhancement of corneal endothelium wound healing by Rho-associated kinase (ROCK) inhibitor eye drops. Br J Ophthalmol. 2011;95(7):1006-9.
69. Okumura N, Koizumi N, Ueno M, Sakamoto Y, Takahashi H, Hamuro J, et al. The new therapeutic concept of using a rho kinase inhibitor for the treatment of corneal endothelial dysfunction. Cornea. 2011;30 Suppl 1:S54-9.

70. Koizumi N, Okumura N, Kinoshita S. Development of new therapeutic modalities for corneal endothelial disease focused on the proliferation of corneal endothelial cells using animal models. Exp Eye Res. 2012;95(1):60-7.

71. Bednarz J, Teifel M, Friedl P, Engelmann K. Immortalization of human corneal endothelial cells using electroporation protocol optimized for human corneal endothelial and human retinal pigment epithelial cells. Acta Ophthalmol Scand. 2000;78(2):130-6

72. Yokoi T, Seko Y, Yokoi T, Makino H, Hatou S, Yamada M, et al. Establishment of functioning human corneal endothelial cell line with high growth potential. PloS One. 2012;7(1):e29677.

73. Fan T, Zhao J, Ma X, Xu X, Zhao W, Xu B. Establishment of a continuous untransfected human corneal endothelial cell line and its biocompatibility to denuded amniotic membrane. Mol Vis. 2011;17:469-80

74. Balachandran C, Ham L, Verschoor CA, Ong TS, van der Wees J, Melles GR. Spontaneous corneal clearance despite graft detachment in descemet membrane endothelial keratoplasty. Am J Ophthalmol. 2009;148(2):227-34.e1.

75. Dirisamer M, Dapena I, Ham L, van Dijk K, Oganes O, Frank LE, et al. Patterns of corneal endothelialization and corneal clearance after descemet membrane endothelial keratoplasty for fuchs endothelial dystrophy. Am J Ophthalmol. 2011;152(4): 543-55.e1.

76. Dirisamer M, Ham L, Dapena I, van Dijk K, Melles GR. Descemet membrane endothelial transfer: "free-floating" donor Descemet implantation as a potential alternative to "keratoplasty". Cornea. 2012;31(2):194-7. 